\title{
Paraganglioma of the cauda equina: a case report
}

\author{
JANICE R ANDERSON,* R W GULLAN $\dagger$ \\ From the Departments of Histopathology* and Neurosurgery, $\dagger$ Addenbrooke's Hospital, Cambridge, UK
}

SUMMARY This case report describes a paraganglioma of the cauda equina in a 63 year old woman. Very few examples of paraganglioma have been recorded in this site. Histologically these neoplasms may have considerable similarity with ependymoma, the most common neoplasm of the lower spinal cord, and the diagnosis can be easily missed unless special techniques are employed. The clinical and pathological data obtained from this and the other reported examples suggests that paragangliomas of the cauda equina are benign, slowly growing neoplasms. In contrast to ependymomas and to paragangliomas elsewhere, they are well circumscribed, amenable to complete resection and have an excellent prognosis.

Paragangliomas are neoplasms that are thought to arise from cells containing catecholamines, which are widely distributed throughout the body in association with the autonomic nervous system. ${ }^{1}$ Extra-adrenal tumours occur most often in the carotid body, glomus jugulare, mediastinum and para-aortic region. Paragangliomas from different sites show variable light microscopic patterns. An arrangement of compact cell nests is common, but the key diagnostic feature is the presence of cytoplasmic granules, only demonstrated reliably by electron microscopy. ${ }^{1}$ These are electron dense, spherical, neurosecretory type granules, 100-200 $\mathrm{nm}$ diameter. The granules contain catecholamines, but in extra-adrenal sites the majority of these neoplasms are non-functional.

\section{Case report}

\section{Clinical features}

A 63 year old woman presented with a 12 year history of pain in her left buttock radiating to the posterior aspect of her left thigh. Initially she had ignored her symptoms which were intermittent, but 2 months prior to admission her pain became almost continuous and was exacerbated by exercise. Her walking distance progressively diminished and exercise

†Present address, Department of Neurosurgery, The Maudsley Hospital, Denmark Hill, London SE5 8AZ.

Address for reprint request: Dr J R Anderson, Department of Histopathology, Addenbrooke's Hospital, Cambridge CB2 2QQ, UK.

Received 20 August 1985 and in revised form 7 January 1986. Accepted 13 January 1986. provoked a feeling of severe numbness in her left buttock and sacral area. She also began to experience a feeling of incomplete emptying of her bladder after micturition. Her general health was good.

On admission the only abnormal physical signs observed were in the skeletal and nervous systems. She showed a mild increase in the lumbar lordosis, associated with slight loss of flexion. There was a slight loss of sensation over the left buttock and sacral area and also the anterior aspect of the left leg. The left ankle jerk was moderately reduced. There was no significant loss of straight leg raising. Radiographs of the lumbo-sacral spine showed scalloping of the posterior aspect of the vertebral bodies with enlargement of the interpeduncular distances at the levels L1-S1. A myelogram demonstrated an intradural lesion occupying the lumbo-sacral canal from L2-S1.

\section{Surgical procedure}

When the dura was opened, after total laminectomy from L2 to $\mathrm{S} 1$, a dark red-brown tumour was exposed, extending from the level of L2 to S1. It appeared to arise from a lower nerve root on the left side and was firm and encapsulated. It required debulking with a Cavitron to aid dissection off the adherent nerve roots, before a complete removal could be performed. After operation she made an excellent recovery with greatly improved sacral sensation, but the left ankle jerk remained diminished. She did not receive post-operative radiotherapy. Twenty months later she is well with no evidence of tumour recurrence.

\section{Histology}

The resected tumour was light brown in colour, with a smooth surface and measured $7.0 \times 3.0 \times 2.0 \mathrm{cms}$. Histology revealed a densely cellular tumour composed of cuboidal to columnar cells with uniform rounded nuclei (fig 1). Mitotic figures were not apparent. In parts the 


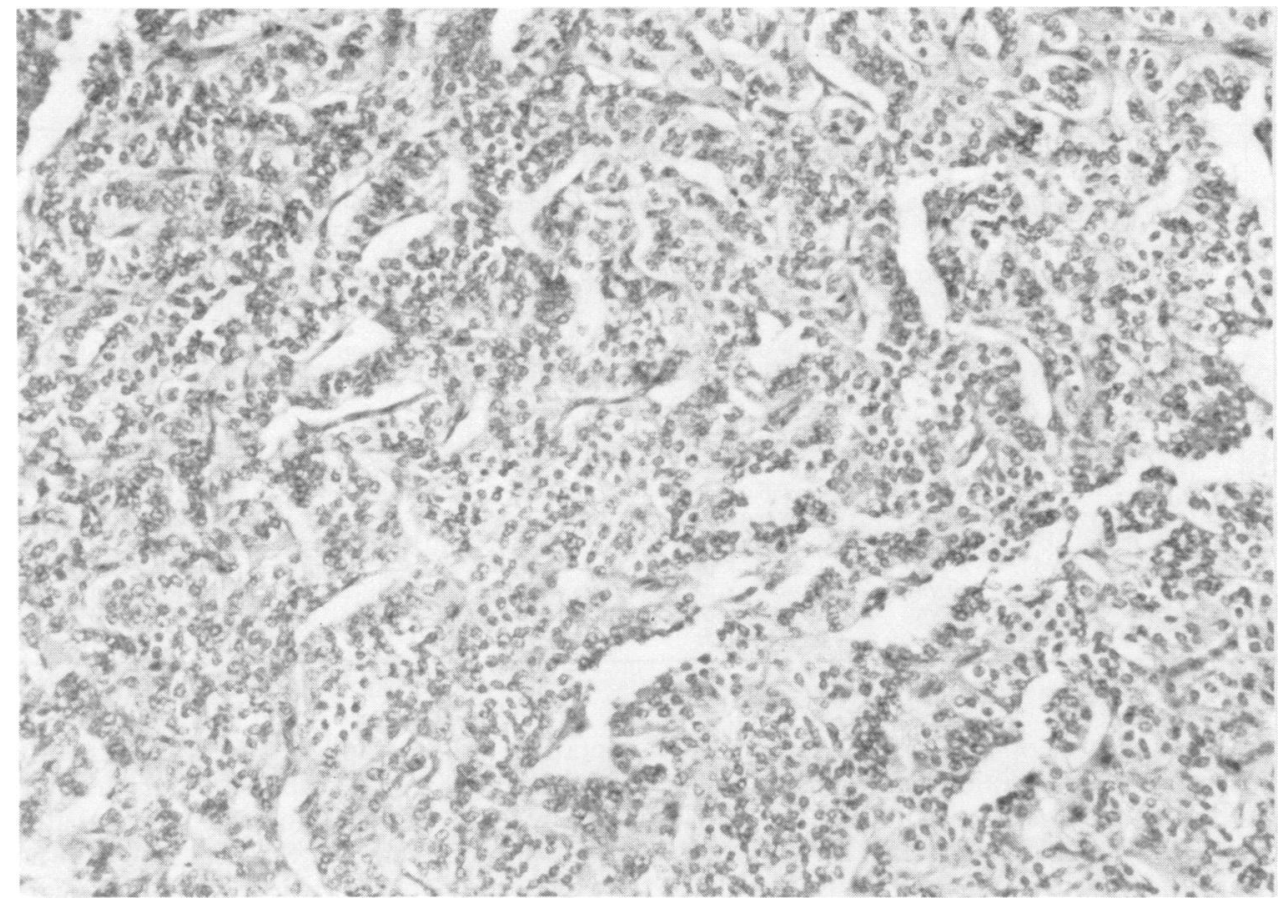

Fig 1 Tumour composed of cuboidal to columnar cells with uniform, small, rounded nuclei. Clefts and a ribbon-like pattern are apparent. A similar appearance may be found in ependymomas. (Haematoxylin and eosin $\times 130$.)

tumour cells showed clear cytoplasm and a packeted arrangement, elsewhere there was eosinophilic cytoplasm and a ribbon-like pattern (fig 1). There were occasional perivascular pseudorosettes, but no true rosettes. Intercellular stroma was scanty and inconspicuous throughout. A negative result was obtained with the immunoperoxidase method for glial fibrillary acidic protein. No mucin was demonstrable with either the periodic acid Schiff or alcian blue stain. The Grimelius silver staining method demonstrated fine cytoplasmic granules in many tumour cells.

Electron microscopy of formalin fixed tumour material revealed closely packed, interdigitating tumour cells with lucent cytoplasm. Small desmosomes were fairly common. There were occasional cells with dense cytoplasm. Numerous, small, rounded, membrane bound dense core granules, $100-200 \mathrm{~nm}$ diameter were evident in the cytoplasm of the majority of cells (fig 2). In addition many contained stacks of rough endoplasmic reticulum and in a few there were dense clumps of microfilaments. No microvilli or cilia were identified, although there were a few structures resembling ciliary basal bodies. These were in cytoplasm, unrelated to the cell membrane and were interpreted as centrioles. These findings established the diagnosis of paraganglioma.

\section{Discussion}

The paucity of reported cases of paraganglioma of the cauda equina suggest that either this is an extremely rare entity or one that has been frequently mis- diagnosed. Probably both these statements are valid. This case emphasises the histological similarity with ependymoma, which is well documented as the most common neoplasm at this site. ${ }^{2}$ It is important to be aware of the microscopic similarity so that appropriate special stains and electron microscopy can be employed to make the diagnosis. Accurate histo-

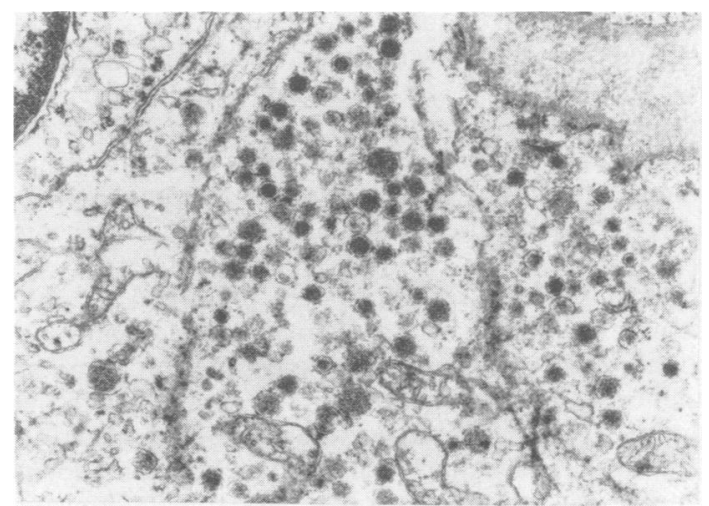

Fig 2 Numerous dense core granules in tumour cell cytoplasm. The granules have an outer membrane and dense central core, characteristic of catecholamine storing granules in normal paraganglion cells. (Electron micrograph $\times$ 8000.) 
Table Data from reported cases of paraganglioma of the cauda equina

\begin{tabular}{|c|c|c|c|c|c|c|}
\hline Author(s) & $\begin{array}{l}\text { Age } \\
\text { (yr) }\end{array}$ & Sex & $\begin{array}{l}\text { Length of } \\
\text { history }\end{array}$ & Clinical presentation & Size & Follow up \\
\hline Miller \& Torack ${ }^{3}$ & 56 & $\mathbf{F}$ & $15 \mathrm{yr}$ & $\begin{array}{l}\text { Low back pain, leg weakness, } \\
\text { urinary incontinence }\end{array}$ & $26 \mathrm{gms}$ & $\begin{array}{l}3 \text { mo NRT, weak legs, incontinence } \\
\text { urine and faeces }\end{array}$ \\
\hline $\begin{array}{l}\text { Lerman et } a l^{4} \\
\text { Horoupian et } a l^{5}\end{array}$ & $\begin{array}{l}29 \\
59\end{array}$ & $\begin{array}{l}\mathbf{M} \\
\mathbf{F}\end{array}$ & $\begin{array}{l}13 \mathrm{mo} \\
1 \mathrm{yr}\end{array}$ & $\begin{array}{l}\text { Low back pain, worse on exercise, } \\
\text { Low back pain worse on movement, } \\
\text { retention of urine }\end{array}$ & $\begin{array}{l}2 \mathrm{cms} \\
1.5 \mathrm{cms}\end{array}$ & $\begin{array}{l}18 \text { mo NRT } \\
8 \text { mo NRT neurogenic bladder, weak } \\
\text { leg }\end{array}$ \\
\hline $\begin{array}{l}\text { van Alpen et } a l^{6} \\
\text { Lagace } e t a l^{7}\end{array}$ & $\begin{array}{l}44 \\
55\end{array}$ & $\begin{array}{l}\mathbf{M} \\
\mathbf{M}\end{array}$ & $\begin{array}{l}6 \mathrm{mo} \\
3 \mathrm{yr}\end{array}$ & $\begin{array}{l}\text { Low back pain } \\
\text { Low back pain worse on exercise }\end{array}$ & $\begin{array}{l}3.5 \mathrm{cms} \\
2.5 \mathrm{cms}\end{array}$ & $\begin{array}{l}2 \text { mo NRT } \\
26 \text { mo well, DXT post-op, removal } \\
\text { incomplete }\end{array}$ \\
\hline $\begin{array}{l}\text { Llena et } a l^{8} \\
\text { Binkley et } a l^{9}\end{array}$ & $\begin{array}{l}41 \\
66\end{array}$ & $\begin{array}{l}\mathbf{M} \\
\mathbf{M}\end{array}$ & $\begin{array}{l}7 \mathrm{yr} \\
3 \mathrm{yr}\end{array}$ & $\begin{array}{l}\text { Low back pain, acute urinary retention } \\
\text { Low back pain, weak legs, retention of } \\
\text { urine }\end{array}$ & $\begin{array}{l}8 \mathrm{cms} \\
6 \mathrm{~cm}\end{array}$ & $\begin{array}{l}\text { Fit } 2 \text { weeks post-op } \\
8 \text { mo NRT neurogenic bladder, weak } \\
\text { leg }\end{array}$ \\
\hline $\begin{array}{l}\text { Llena et } a l^{10} \\
\operatorname{Taxy}^{11}\end{array}$ & $\begin{array}{l}42 \\
52\end{array}$ & $\begin{array}{l}\mathbf{M} \\
\mathbf{M}\end{array}$ & $\begin{array}{l}4 \mathrm{yr} \\
5 \mathrm{yr}\end{array}$ & $\begin{array}{l}\text { Low back pain } \\
\text { Low back pain, weak leg }\end{array}$ & $\begin{array}{l}3.5 \mathrm{cms} \\
\text { Not stated }\end{array}$ & $\begin{array}{l}1 \text { yr well NRT } \\
\text { Incomplete removal, post-op DXT, } \\
\text { recurrence after } 9 \text { years }\end{array}$ \\
\hline $\begin{array}{l}\text { Soffer et al }{ }^{12} \\
\text { Cabello \& Ricoy }{ }^{13} \\
\text { Lipper \& Decker }{ }^{14} \\
\text { Anderson \& Gullan (present } \\
\text { case) }\end{array}$ & $\begin{array}{l}44 \\
13 \\
64 \\
29 \\
56 \\
63\end{array}$ & $\begin{array}{l}\mathbf{F} \\
\mathbf{M} \\
\mathbf{F} \\
\mathbf{M} \\
\mathbf{F} \\
\mathbf{F}\end{array}$ & $\begin{array}{l}5 \mathrm{mo} \\
2 \mathrm{mo} \\
4 \mathrm{mo} \\
2 \mathrm{mo} \\
10 \mathrm{yr} \\
12 \mathrm{yr}\end{array}$ & $\begin{array}{l}\text { Low back pain } \\
\text { Low back pain } \\
\text { Low back pain } \\
\text { Low back pain } \\
\text { Low back pain worse on exercise } \\
\text { Low back pain, incomplete emptying } \\
\text { of bladder }\end{array}$ & $\begin{array}{l}3 \cdot 5 \mathrm{cms} \\
2 \mathrm{cms} \\
2.5 \mathrm{cms} \\
2.7 \mathrm{cms} \\
3 \cdot 5 \mathrm{cms} \\
7 \mathrm{~cm}\end{array}$ & $\begin{array}{l}15 \text { mo NRT } \\
\text { Well post-op } \\
\text { Not stated } \\
\text { Not stated } \\
7 \text { mo NRT slight weakness of foot } \\
20 \text { mo well NRT }\end{array}$ \\
\hline
\end{tabular}

NRT-no recurrence of tumour.

DXT-radiotherapy.

genetic classification of neoplasms is not just an academic exercise, but an important basis for selection of appropriate therapy, surgery, radiotherapy or adjuvant chemotherapy. It is important to segregate tumours which may have a different natural history, lest their inclusion in any clinical trial biases the results.

In this case, a long clinical history, radiological evidence of chronic bony changes and banal cytology suggest a benign, slowly growing, non-functioning neoplasm. Other reported cases lend support to this view. There is a fairly consistent record of a long history, often several years, of low back pain, prior to diagnosis (table). This is such a common clinical complaint that only exacerbation or the advent of additional neurological problems, such as leg weakness, bowel or bladder symptoms may prompt investigations. Urinary retention has been reported in several instances. ${ }^{589}$ In almost every case surgery has revealed a well circumscribed ovoid to cylindrical intradural, extramedullary tumour, with maximum dimension of a few centimetres, hence complete surgical resection has been possible (table). In a few cases it has been necessary to incise an adherent nerve root, but usually neural tissue has been preserved. In only one case, described as a secretory ependymoma, but probably the first reported example of a paraganglioma, was the filum terminale removed with the tumour. ${ }^{3}$ The local infiltrative growth, and spread to extradural soft tissue, that may occur with ependymoma, has not been described in paraganglioma at this site. Primary surgical excision appears to be the treatment of choice. As yet there has been no local recurrence after total macroscopic surgical removal (table). One case incompletely excised and given post- operative radiotherapy recurred 9 years after the initial operation. ${ }^{11}$ Another tumour that was only partially removed is said to have regressed after postoperative radiotherapy. ${ }^{7}$ Surgical resection has usually produced considerable relief of clinical symptoms. Mild neurological deficit has persisted in those patients where it was most severe preoperatively or where nerve roots were excised at operation. The available data suggest that paragangliomas of the cauda equina are slowly growing, well circumscribed neoplasms that may be cured by surgery alone. However, it is well known that paragangliomas in other locations, for example the retroperitoneum and larynx, have a poor prognosis, with high morbidity and eventual mortality, ${ }^{1}$ hence there is a need for further documentation of the paragangliomas of the cauda equina, in order to establish whether or not their behaviour is uniformly benign.

\section{References}

1 Glenner GG, Grimley PM. Tumours of the extraadrenal paraganglion system. In: Atlas of Tumour Pathology. Washington DC: Armed Forces Institute of Pathology, 1974.

2 Russell DS, Rubenstein LJ. Pathology of Tumours of the Nervous System. Edition 4, Edinburgh: Edward Arnold, 1977:205-6.

3 Miller CA, Torack RM. Secretory ependymoma of the filum terminale. Acta Neuropathol (Berl) 1970;15: 240-50.

4 Lerman RI, Kaplan ES, Daman L. Ganglioneuromaparaganglioma of the intradural filum terminale. Case report. J Neurosurg 1972;36:652-8.

5 Horoupian DS, Kerson LA, Saiontz H, Valsamis M. 
Paraganglioma of cauda equina: Clinicopathologic and ultrastructural studies of an unusual case. Cancer 1974;33:1337-48.

6 van Alpen HAM, Bellot SM, Stam FC. Paraganglioma of cauda equina. Clin Neurol Neurosurg 1977;79: 316-22.

7 Lagace R, Delage C, Gagne F. Paraganglioma of the filum terminale. Can J Neurol Sci 1978;5:257-60.

8 Llena JF, Hirano A, Rubin RC. Paraganglioma of the cauda equina. Acta Neuropathol (Berl) 1979;46: 235-7.

9 Binkley W, Vakili ST, Worth R. Paraganglioma of the cauda equina. $J$ Neurosurg 1982;56:275-9.

10 Llena JF, Wisoff HS, Hirano A. Gangliocytic para- ganglioma in cauda equina region, with biochemical and neuropathological studies. $J$ Neurosurg 1982;56: 280-2.

11 Taxy JB. Paraganglioma of the cauda equina. Report of a rare tumour. Cancer 1983;51:1904-6.

12 Soffer D, Pittaluga S, Caine Y, Feinsod M. Paraganglioma of cauda equina. A report of case and review of the literature. Cancer 1983;51:1907-10.

13 Cabello A, Ricoy JR. Paraganglioma of the cauda equina. Cancer 1983;52:751-4.

14 Lipper S, Decker RE. Paraganglioma of the cauda equina. A histologic, immunohistochemical, and ultrastructural study and review of the literature. Surg Neurol 1984;22:415-20. 